and the analyses and investigations of various minerals. The report directs attention to the wide range of valuable minerals produced in the Union of South Africa. The use made by the public of the exhibition galleries, and the provisions made for educational purposes are dealt with in the report, which indicates clearly the very useful purposes served by the Imperial Institute.

\section{The Italian Seismological Society}

THIs well-known Society has now existed for forty years, and the first number of the new volume of the Bollettino $(33,10-21$; 1935) contains a brief survey of its history by the present secretary, Prof. G. Agamennone. The study of earthquakes as a whole in Italy may be said to have begun in 1870 with the works of Bertelli and De Rossi ; but the issue of the Bullettino del Vulcanismo Italiano, founded by the latter in 1874, was declining after twenty years. The Italian Society, in imitation of its Japanese predecessor, was founded in 1895 under the direction of Prof. P. Tacchini, the director of the Central Office of Meteorology and Geodynamics, and continued ten years later under that of his successor Prof. L. Palazzo, the present president being Prof. G. Cicconetti. The activity of the Society may be judged from the volumes of the Bollettino so far published, which contain nearly 500 papers occupying more than 9,000 pages.

\section{Cambridge Microtomes}

THIs year the Cambridge rocking microtome, one of the most familiar instruments in biological laboratories, attains its jubilee. The Cambridge Scientific Instrument Co., Ltd., has issued a new folder, illustrating this instrument and also a more heavily built and modified form of it for cutting flat sections of larger objects. The folder shows in addition a massively built sliding microtome, the design of which was completely overhauled two years ago, which cuts large sections, $60 \mathrm{~mm} . \times 60 \mathrm{~mm}$, in either paraffin or celloidin, and a freezing microtome of new design. Hints on the care and sharpening of microtome knives are added.

\section{International Society of Leather Trades' Chemists}

THE bi-annual conference of the International Society of Leather Trades' Chemists, in conjunction with that of the Internationalen Vereins der Leder Industrie Chemiker, will be held on September 1-6 at the Institut des Arts et Metiers, 50 Boulevard de l'Abattoir, Brussels, Belgium. The reception of members and visitors will take place on Sunday evening, September 1, at 8 p.m., at the Palace Hotel, Place Rogier, while the official banquet, at which the Burgomaster of Brussels will be present, together with other representatives of civic, commercial and scientific bodies, is fixed for Wednesday, September 4 . Some thirty papers are to be read and discussed. Further details can be obtained from M. A. Fievez, 7 rue d'Audiger, Soignies, Belgium, or from the Honorary General Secretary of the I.S.L.T.C., 17 Market Street, London, S.E.1.

\section{Announcements}

Prof. J. A. Nrxon and Dr. R. E. Lane have been appointed to fill vacancies in the membership of the Industrial Health Research Board.

THE following appointments have recently been made by the Secretary of State for the Colonies: Mr. A. W. Gledhill, to be veterinary officer, Uganda; Mr. R. M. Davies, district agricultural officer, Tanganyiki, to be senior agricultural officer; Mr. S. P. Teare, game ranger, Tanganyika, to be game warden.

THE Managers of the Royal Institution have awarded the Dewar research fellowship to $\mathrm{Mr}$. A. R. Ubbelohde, formerly Senior Scholar of Christ Church, Oxford, and at present holder of a senior research award of the Department of Scientific and Industrial Research. Mr. Ubbelohde will take up his new appointment in the autumn. His researches have been largely in physical chemistry, and it is expected that his experience will be valuable in connexion with the researches directed by Sir William Bragg at the Royal Institution on the structure of matter.

Applications are invited for the following appointments, on or before the dates mentioned:

Scientific Officers (Ref. A. 764), junior scientific officers (Ref. A. 765), and assistants, grades I-III (Ref. A. 766-8) at the Royal Aireraft Establishment, South Farnborough, Hants-The Chief Superintendent (Aug. 17).

An assistant signals officer and a signals officer in the Signals Branch, Air Ministry-The Secretary (S 1, Room 436), Air Ministry, Adastral House, Kingsway, W.C.2 (Aug. 19).

A senior lecturer in the Department of Pure and Applied Science, Loughborough College-The Registrar (Aug. 24).

An engineer officer in the Public Works Department, Buildings and Roads Branch, Punjab-The High Commissioner for India, General Department, India House, Aldwych, London, W.C.2 (Aug. 26).

An assistant lecturer in the Department of Zoology, University of Leeds-The Registrar (Aug. 31).

An assistant lecturer in the Department of Physiology, University College of South Wales and Monmouthshire-The Registrar (Aug. 31).

A lecturer in morbid anatomy in the Department of Pathology, University of Aberdeen--The Secretary (Sept. 15).

A professor of mathematics in the University of Aberdeen-The Secretary (Sept. 30).

Temporary architectural and engineering assistants in the Directorate of Works and Buildings, Air Ministry, and at various aerodromes in the United Kingdom-The Secretary (W.B.9, Room 161), Air Ministry, Adastral House, Kingsway, W.C.2.

Temporary assistant mechanical and electrical engineers-The Secretary, Air Ministry (W.B.9), Adastral House, Kingsway, London, W.C.2.

A lecturer in geography and mathematics at St. Hild's College, Durham (Diocesan Training College for Women)-The Principal. 